\title{
THE LINGUISTIC MODELING OF VARIATION IN ISLAM: CONSTRUCTING SAUSSURE'S CONCEPTS OF LANGUE AND PAROLE TO RELIGIOUS STUDIES
}

\author{
RONALD LUKENS-BULL ${ }^{1}$ \\ KRISTEN ANGELUCCI ZAHN \\ University of North Florida
}

\section{Abstract}

Islam has some basic set of shared symbols, beliefs, and rituals that are found in the Quran and Hadith. These form the foundations of universal Islam. But even with the "universal" foundations of Islam we find considerable debate and disagreement. Dealing with the diversity in Islam, we will develop our model, especially through the more complete linguistic analogies. The core of our model borrows Saussure's concepts of langue (language as a system) and parole (speech acts) and applied it to religion. The transcendent form of a religion, which is parallel to langue, is an ideal form in the minds and hearts of believers. The expressed form, which is analogous to parole, includes interpretations, discourse, debates, rituals, and daily life of believers. The aim of this paper is more to elucidate an analytical model than to make declarative statements about the nature of religion. We argue that a fuller linguistic analogy moves us further in our understanding of this relationship. The results of the analysis show that linguistic modeling of variation in Islam applied through several ways, there are: (1) dialects and local religious practice (2) the transcendent and the expressed as parallels to Saussure's langue and parole (3) linguistic analogies (4) myth, doctrine, and grammar (4) syntax, Islam and ritual and (5) creoles and pidgins.

Corresponding author; email: ${ }^{1}$ rlukens@unf.edu. The authors would like to thank Ronald Kephart, Katryne Lukens-Bull, and Mark Woodward for their assistance and insights. 
Islam memuat sekumpulan unsur-unsur, baik simbol, keyakinan, dan ritual-ritual yang dapat dijumpai dalam al-Quran dan Hadis. Hal ini yang kemudian membentuk dasar-dasar Islam universal. Namun, babkan dengan dasar-dasar Islam "universal" tersebut, kita masih menemukan perdebatan dan perselisihan. Berkaitan dengan keragaman dalam Islam tersebut, penulis akan mengembangkan sebuah model, terutama melalui analogi-analogi linguistik yang lebih lengkap. Inti dari model ini meminjam konsep bahasa Saussure, tentang langue (bahasa sebagai sistem) dan parole (tindak tutur) dan mengkaitkanya dengan diskursus agama. Bentuk transenden dari agama sejajar dengan konsep langue, yakni bentuk ideal dalam pikiran dan hati pemeluk agama. Sementara Bentuk yang diekspresikan, dianalogikan dengan parole, termasuk interpretasi, wacana, perdebatan, ritual, dan kehidupan sehari-hari pemeluk agama. Tujuan dari penelitian ini lebih untuk menjelaskan model analitis daripada sekedar membuat pernyataan deklaratif tentang agama. Penulis berpendapat bahwa analogi linguistik yang lebih lengkap menggerakkan kita lebih jauh pada pemahaman tentang hubungan lingustik dan agama. Hasil analisis menunjukkan bahwa model variasi linguistik dalam Islam muncul melalui beberapa hal, yaitu: (1) dialek dan praktek keagamaan lokal (2) transenden dan ekspresi sebagai kesejaja-ran dengan konsep langue dan parole Saussure (3) analogi-analogi linguistik (4) mitos, doktrin, dan tata bahasa (4) sintaksis, islam dan ritual (5) creole dan pidgin.

Keywords: creoles and pidgins; Islam; langue and parole; linguistic; religious studies.

\section{Introduction}

More than a decade ago, Ronald Lukens-Bull (1999) argued that the anthropological study of Islam was plagued by problems of definition. In short, the problem concerned understanding the relationship between local practices and understandings, and universal Islam-whatever that might be. This theoretical issue is neither restricted to Islam nor is it more thorny for the 
study of Islam that it is for any other world religion. Rather it is the authors' familiarity with Islam that focuses our attention there.

Although there have been recent and laudable attempts to address the anthropology of Islam (Varisco 2005; Marranci 2008), these efforts have not shed much light on how to approach the simultaneous unity and diversity in Islam. The question remains how to do we make sense of diverse practices? How to we account for practices such as the Javanese Horse Trance ritual, in which dancers are placed into a trance by a shaman who gets his power from meditating at the grave of a medieval Islamic saint. In trance, they enact the events that befell those that fought the expansion of the Islamic kingdom of Mataram. They are said to have became possessed by the spirits of their own horses and ran around crazy. The trancers eat rose petals, tear open coconuts with their teeth, roll on glass, dance on fire, pierce their cheeks with pins and they do not get hurt. The message to the villagers is clear-embrace Islam and be protected; reject Islam and go insane (Hartley 1974). Although this particular example may be an outlier, there are many others to include such as ziarah or pilgrimage to saints' graves (Bhardwaj 1998; Chambert-Loir and Reid 2002; Subtelny 1989), the keeping of spirit familiars (Saniotis 2004) and the Mevlevi Order, better known as the Whirling Dervishes (Friedlander 1992). When we add the Nation of Islam with its unorthodox doctrine (Lee 1996), al-Qaeda (Gunaratna 2002) and Muslim Radicals we are faced with having to explain how a disparate set of practices and practitioners are related. Not only must we consider what ties them together but also what distinguishes them from each other. As Roy avers,

The notion of a single 'Muslim culture' cannot survive analysis. If it refers to Islam as a religion it is redundant. The different Muslim populations have some element in common such as 
diet and holidays, which are nothing more than the basic tenets of the rituals and beliefs, but in themselves, they do not constitute a culture. What is beyond the strict tenets of religious rituals and beliefs refers to specific national or ethnic cultures, or which Islam is just a component, even it is indistinguishable (Roy 2004, 129).

This is not a particularly new observation, even scholars now denigrated by some as "Orientalists" observed that "Islam does not have the uniformity of a church" (Goldziher 1910). Goldziher demonstrated the dynamics of diversity evident in Islam from early in its history to the time of his writing (ca. 1910). The worldwide Islamic community, even within each major section, is typified by cultural diversity (Davies 1988). Neither great nor little traditions are unified wholes. Even the so-called "little tradition" of a single village is not unified (Antoun 1989, 39; Loeffler 1988). Therefore, it is critical to consider the relationships of Universal Islam, local Islams, and received Islam. This is what Talal Asad $(1986,5)$ calls for when he suggested that the anthropology of Islam must devise a conceptual organization of the diversity in Islam.

Obviously, there is some basic set of shared symbols, beliefs, and rituals that are found in the Quran and Hadith. These form the foundations of universal Islam. But even with the "universal" foundations of Islam we find considerable debate and disagreement. Not all Hadith are accepted as sound and even if there is little room for debate among Muslims on the soundness of Quranic verses, there is considerable debate on how to best interpret many passages

After reviewing the various ways anthropologists have proposed how to deal with the diversity in Islam, we will develop our model. Although partial linguistic analogies have been suggested before, we will argue for a more complete linguistic model. The core of our model borrows Saussure's (1972) con- 
cepts of langue (language as a system) and parole (speech acts) and applies it to religion. The transcendent form of a religion, which is parallel to langue, is an ideal form in the minds and hearts of believers. The expressed form, which is analogous to parole, includes interpretations, discourse, debates, rituals, and daily life of believers. The expressed form is all that is accessible to the anthropologist. The aim of this paper is more to elucidate an analytical model than to make declarative statements about the nature of religion.

\section{Earlier Approaches}

An early approach to the diversity in world religions is Robert Redfield's notion of great and little traditions (Redfield 1956) which came to be one way to solve the problem of diversity in Islam (Asad 1986, 5). In its most developed form, the great and little traditions model was employed as a means of understanding the relationship between the traditions known via religious texts and the expression of those concepts within a folk or cultural context (Eickleman 1982, 59).

Although not what Redfield intended, the dichotomy allowed scholars to treat great and little traditions as isolates with anthropologists staying in their comfort zone in villages and allowing Orientalists to stay in their comfort zone of texts (Bowen 1993a, 185). This, however, leads to an overly narrow view of the tradition and a tendency to see the universal aspects of the tradition as the core of Islam. Further, this "lent a normative and cultural priority to the Middle East vis-a-vis the rest of the Muslim world" (Bowen 1993b, 6). Bowen states that anthropologists and other scholars concerned with local forms of culture looked for the rites, myths, or ideas that made the group they were studying distinctive rather than focusing on those they shared with other Muslims (Bowen 1993b, 4). 
El-Zein $(1977,243)$ argues that the dichotomy of folk Islam (little tradition) versus elite Islam (great tradition) is infertile and fruitless primarily because it privileges elite Islam and regards local Islam "less ordered, less objective, and somehow less complete versions of the religious experience”. He argues that various theological and anthropological interpretations of the meaning of Islam are dependent upon assumptions which define and limit what can be properly considered "religious" and "Islamic". These assumptions distinguish a "folk from an elite, and a real from a false Islam" (El-Zein 1977, 249). El-Zein $(1977,246)$ suggests that it is ironic that anthropology studies folk Islam while using the principles of elite Islam. We agree with el-Zein that a rigid dichotomy is fruitless. However, we must recognize that there is variation in Islam and despite that variation, there are commonalities that come from interaction between local practices and some more transcendent form as well as interaction between different local "Islams." Here we seek to develop a model that will show how the variations may influence each other

Redfield's approach has largely been rejected but it has not been entirely abandoned. There is still intense theoretical interest in the relationship between what people do and what some text might be interpreted as saying what they should do. A variation would be to assert that anthropologists study Muslims and not Islam (Marranci 2008, 7). Once when the first author said this to a young public school Islam teacher in Malaysia, the teacher seemed mildly offended and challenged, "how can you possibly understand Muslims without studying Islam?" In one sense, you cannot. The renowned ethnographer of Islam in Southeast Asia, the late Clifford Geertz (cf. 1960) learned all he needed to know about Islam from his informants and really did not try to place local practice into the context of the global Muslim community 
or this overarching religion called Islam. And in doing so, he missed something critical. As the young teacher pointed out, "we all share the very same core beliefs."

Talal Asad identified three common approaches to diversity in Islam that move beyond great and little traditions. The first suggests that there is "no such theoretical object as Islam" and therefore there is no need to deal with the diversity between Muslim societies. This approach is currently expressed in the rejection of the term and the very concept of the "Muslim World" which is discussed more in news articles (Khanna 2009) and online conversations (October 2009) than academic articles. The claim is that there is not sufficient similarity between various Muslim societies to categorize them vis-a-vis non-Muslim societies. And yet Islamaphobes and Muslim preachers alike allude to a Muslim civilization or a brotherhood of Muslims. While we can discount hate-mongering views of a unified threat from 1 billion Muslims (and correctly so), we cannot be dismissive of the Muslim notion of $u m m a b^{2}$ and that at some level all believers are interconnected.

The second approach identified by Asad uses Islam as a label for a "heterogeneous collection of items, each of which has been designated Islamic by informants" $(1986,2)$. Asad rejects what might be called a typical anthropological approach to Islam, by asserting the idea;

Islam is simply what Muslims everywhere say it is-will not do, if only because there are everywhere Muslims who say that what other people take to be Islam is not really Islam at all (Asad 1986, 2)

Recently, Gabriele Marranci argued that the core of an Is-

${ }^{2}$ The Muslim concept of ummah is fluid and contested, but nonetheless is an important component of Muslim identity. 
lamic identity is neither tradition nor text but whether or not people "feel" themselves to be Muslims. He suggests "... emotions and feelings should be at the center of our studies of Islam" (Marranci 2008, 6). Further, he argues,

Fieldwork ... should incorporate an analysis of the emotional context within which we operate as anthropologists. This means refocusing our attention to how human beings make sense of the 'map' that we call Islam. To do so we need to observe interpretations of Islam as part of networks of shared meanings ... to observe concepts ... as the result of interpretations affected by personal identity, emotions, feelings, and the environment... (Marranci 2008, 6).

Marranci has a valid point, however, before someone can "feel" themselves to be Muslim, Scottish, a Boy Scout, a good father, or any other identity, they must have some idea what the relevant category means. Further, they must belong to a community that has a (differentially) shared conception of what constitutes those categories. In other words, they have to engage the universal aspect and create a local expression of it. Whether we use the terms great and little traditions, the universal and the local, the textual and the popular, the territory and the map, we are describing the same phenomena.

The third approach holds that Islam is a "distinctive historical totality which organizes various aspects of social life" (Asad 1986, 1). This approach can yield proto-theological ${ }^{3}$ perspectives such as Asad's which privileges discourse about orthodoxy (Marranci 2008, 42). It is essential that anthropologists not favor elite, orthodox forms over local, popular forms. When they do, they miss important dimensions of religious dynamics. For example, Clifford Geertz's Religion of Java (1960) focused

${ }^{3}$ In an earlier article, Lukens-Bull (1999, 43-44) argued that Asad's approach was theological. He now agrees with Gabrielle Marranci $(2008,42)$ that it is proto-theological. 
on local forms and did not see how communal meals, like the slametan are part of larger patterns of Muslim ritual (Woodward 1988). Nor did Geertz recognize the Sufi underpinnings of the practices of Javanese nobles (Woodward 1989).

All three basic approaches fail to examine the specific relationships between the universal and what is practiced at any given time and place. The most insightful contemporary theories regarding this relationship have attempted to explain variation within Islam by constructing linguistic analogies, including studying religion as discourse (Asad 1986; Bowen 2012). Mark Woodward's definitions of the components of Islamic discourse shed light on its nature. He argues that the universal Islam with which local islams interact is concerned with far more than the Quran and Hadith. It includes rituals such as the hajj, the șalāt, 'id al-adha, 'id al-fttr, and the fast of Ramadan among others. However, local Islams do not enter into discourse with the entire Universal corpus of Islam. Received Islam is what Woodward calls that portion of universal Islam present in specific local contexts. Local Islams are those rituals and texts, both oral and written that are not known outside of a specific local context. These local rituals and texts arise from the interaction of local culture and received Islam (Woodward 1988, 87-88). Further, local Islams can interact with each other (Woodward 1988, 65). While useful, Woodward's model does not examine exactly how the universal and local actually interact. We argue that a fuller linguistic analogy moves us further in our understanding of this relationship.

\section{Dialects and Local Religious Practice}

The foundation of our model is understanding Religion as analogous to Language and local variations of a religion like Islam as analogous as dialects. Once Islam was brought to a 
new area like Southeast Asia or sub-Saharan Africa, it gained new inflections. Having such a certain disconnect from the rest of the Islamic world, new expressions of Islam would develop. The people in area used the characteristics and practices brought to them, but expounded upon these principals incorporating aspects of their own native culture, and over time, like languages from the same language families, grew further and further apart. Eventually, if left to continue in this cycle, the two would become completely unintelligible to one another, and as such, be "dialects" of the same religious language, or perhaps be regarded as separate entities all together. However, with Islam the hajj and the education of 'ulamā' (Islamic scholars) kept widely dispersed Muslim from becoming entirely isolated.

Some rituals that have been developed in a semi-isolated way as described above are not recognizably Islamic to Muslims from different parts of the world. This suggests the mutually unintelligible component of dialect. Speakers of Standard English (SE) recognize a difference between SE and Southern American English (emically, "Southern twang"). Likewise, members of one religious sub-group may see a difference between their form and that of another sub-group. What this means in religion, is that some believers would consider some "dialects" as being outside the faith.

Thinking of different expressions of Islam as dialects can help us understand some of the dynamics between them. One way to distinguish between dialects is mutual intelligibility. Certainly for religion, we can imagine practices that are not intelligible between two different communities. However, claims of non-intelligibility may be exaggerated in religion as well as in language. Certain language communities may deny similarities with other communities as part of identity politics. For example, once had a long conversation with a Straits Chinese, or $B a$ - 
bah-Nonya, a couple in Malaka, Malaysia in what he had studied as a form of Malay.

When he asked if they regularly spoke Malay instead of Chinese, they denied that the language in which the conversation was being held was Malay; they only spoke Babah-Nonya. This claim was made in a context in which Malay ethnic identity is associated with speaking Malay, having Malay customs, and being Muslim. Straits Chinese, who fit the first two components but not the third, have reason to deny that their language is Malay. Similarly, it is common enough to encounter circumstances in which Muslims may deny that the practices of other Muslims are properly called Islam. The corresponding author has been told most sincerely by Muslim community leaders in the United States that Sufism is not and has never been part of Islam. Historically, this is incorrect, but it represents this kind of claimed unintelligibly.

Another way in which thinking of different expressions of religion as dialects is useful concerns the dynamics between standard and non-standard forms. Prejudice toward non-standard languages is common enough. It leads to a number of problems in education; non-standard languages are not recognized as separate dialects but as "broken" forms of the standard.

\section{The Transcendent and the Expressed}

Our model uses the terms transcendent and express as parallels to Saussure's langue and parole to explore the relationship between ideal types and actual practice. Our use of the term transcendent represents the ideal type of religion sometimes referred to as the universal. We do not intend a mystical understanding in using this term; it simply refers to the dimension of any religion that connects various local practices. It is transcendent in the sense that it is more than the understanding of any 
particular believer or local community of believers. It is also less than the understanding of any particular believer or community of believers; in seeking to understand the transcendent, human beings bring their histories (both personal and communal) and biases.

This is where the expressed form of religion comes into play. The term "expressed religion" encompasses much of what is sometimes called the little tradition or local tradition. However, whereas these terms marginalize non-elite practices, "expressed religion" does not because it also includes the elite forms typically associated with "great traditions". Also part of expressed Islam would be any particular interpretation of the Quran and the Hadith.

The transcendent encompasses all of the possible concepts and ideas that can be drawn upon by a given Islamic community, and the expressed is a specific subset of the transcendent chosen and practiced by that given community. Transcendent Islam includes the complete set of concepts of Islam, as well as "grammar" for compiling the concepts into meaning. Any given concept may or may not be used in a particular form of expressed Islam. In this way, religion is analogous to language. Any given speaker of a language may not know every single word in that language, but the ignorance of a particular speaker does not cause those words to cease to exist. Further, dialects will also have slightly different lexicon.

In this way, the transcendent form of Islam contains all of the possible concepts and ideas that any given Muslim may accept as part of their practice of Islam. The acceptance of a particular expression does not nullify the existence of those other concepts and ideas that are not present in a given practice. The transcendent is an abstraction, something that even attempts to talk about it become an expressed interpretation of it. As such, 
anthropologists may not be able to fully describe or understand the transcendent due to this nature.

\section{Linguistic Analogy: A Foundation}

Saussure, a Swiss linguist, made a distinction between langue and parole. Langue is a

... storehouse filled by the members of a given community through their active use of speaking, a grammatical system that has a potential existence in each brain, or, more specifically, in the brains of a group of individuals. For language is not complete in any speaker, it exists perfectly only within a collectivity.

In separating language (langue) from speaking (parole) we are at the same time separating: (1) what is social from what is individual; and (2) what is essential from what is accessory and more or less accidental (Saussure 1972, 13-14).

Whereas langue is the social side of language and is, according to Saussure, a unitary and equally shared "thing", parole is actual language use (Fairclough 1989, 20). Saussure's definition of langue is analogous to Geertz's definition of culture (Geertz 1973, 4-5). Both definitions hold that a community shares basic symbol systems, whether they are primary systems (as in language) or secondary (as in Geertz's use of “meanings”). Geertz $(1973,164)$ argues that culture is not inside people's head, rather it is embodied in and shared through symbols which have public meanings. In speaking about what connects two different Muslim cultures, Clifford Geertz $(1968,54)$ writes;

"The hope for general conclusions in this field lies not in some transcending similarity in the content of religious experience or in the form of religious behavior from one people to another or one person to another. It lies in the fact or what I take to be a fact, that the field over which that content and that behavior range is not a mere collection of unrelated ideas and emotions and acts, but an ordered universe ...." 
Our goal here is develop a way to model the "ordered universe" of Islam. Our analogy is based on Saussure's explanation of the relationship between langue and parole. Langue represents the unexpressed transcendent, the abstract set of concepts that exists solely within the mind. These concepts are not expressed in their own right, as we posit the transcendent functions as the abstract facet of Islam. This implies that the transcendent, langue, is complete whereas the expressed, parole, is a subset by definition. Saussure suggests that parole or spoken language is not complete within any given speaker of a language, but can only be complete within the minds of the collective unit of speakers of that language (Saussure 1972). Likewise, particular expressed forms of Islam are not complete expressions of the transcendent; it is the global collective community of Muslims where the whole of the transcendent resides. Islam, like language deals with the issues of the transcendent and the expressed in this respect and is the point of entry through which anthropologists can use linguistic analogy to understand Islam.

Our model for understanding the dynamics between the transcendent and expressed forms of Islam expands from seeing analogous processes in religion. Hence, religious concepts or ideas are the basic units of the transcendent ${ }^{4}$. Like morphemes, they come into their full meaning when combined into larger units and become an expression in the practices of the Islamic community.

${ }^{4}$ We are deliberately rejecting the use of the "meme" concept (Dawkins 1976). The idea of memes comes from an attempt to model cultural transmission on genetic transmission; memes are to culture as genes are to phenotype. While there may be some superficial similarity between the "memes" model and our own, our analogy compares religious ideas to phonemes and morphemes. 


\section{Diagrams and Models}

In linguistics, rule diagrams can show how such a relationship can exist between langue (within the mind) and parole (spoken language) and congruently for the transcendent and expressed religious traditions ${ }^{5}$. These diagrams can also emphasize the importance of social context, an element missing in Saussure's model (Voloshinov 1973, 21; Chandler 2006, 14). Lévi-Strauss sought to identify what he called Gross Constituent Units, or mythemes, in his analysis of myth, although he was not concerned, as we are, with showing the relationship between a "mytheme" and its expression (Lévi-Strauss 1998).

In order to gain a better understanding of the terminology and symbols used in the diagrams, we refer to table 1 .

Table 1

Reading rule diagrams

\begin{tabular}{ccc}
\hline Symbol & Linguistic Use & Our Model \\
\hline$\{\#\}$ & Morpheme & $\begin{array}{c}\text { Transcendent } \\
\text { Gross Constituent Units } \\
\text { Greatest level of abstraction }\end{array}$ \\
\hline$[\# /$ & $\begin{array}{c}\text { Allomorph } \\
\text { Phoneme }\end{array}$ & Midlevel \\
\hline$[\#]$ & Allophone & $\begin{array}{c}\text { Expressed } \\
\text { Least Abstract }\end{array}$ \\
\hline
\end{tabular}

Starting at the level of expression, square brackets [\#] indicate the allophone, or the way in which the phoneme is expressed. This is also known as the surface form, which is generated through the application of all rules of a given idiom (linguistic or religious) on a given phoneme, morpheme, or concept. Slashed demarcations around a letter /\#/ indicate the underly-

${ }^{5}$ Chomsky uses slightly different vocabulary in his explanation of these interactions, mechanical and mental interactions, but does so in such a way to show the interfacing of the brain and the act of speaking (Chomsky 2002). 
ing form of a phoneme, and curly brackets $\{\#\}$ indicate the underlying form of the Gross Constituent Units of religion. In a morphemic rule diagram, the pair of slashes /\#/ represents the allomorph or the expressed forms of a morpheme. The second slash indicates "in the context of." The horizontal arrows in the diagrams represent the rules and restrictions that are used to move from the abstract to the concrete.

Figure 1

Contextual expression of phonemes ${ }^{6}$

$$
\begin{aligned}
& / \mathrm{p} \mathrm{t} \mathrm{k} / \Rightarrow\left[\mathrm{p}^{\mathrm{h}} \mathrm{t}^{\mathrm{h}} \mathrm{k}^{\mathrm{h}}\right] / \# \\
& {[\mathrm{p} t \mathrm{k}] /[\mathrm{s}]}
\end{aligned}
$$

In the diagram, figure 1 , the phonemes $/ \mathrm{p} /, \mathrm{t} / \mathrm{\text {,and }} / \mathrm{k} /$ are aspirated at the beginning of a word and unaspirated after an s. The phonological rule analogy operates under the assumptions of the relations between the mechanical and the mental processes of language. In the example below, the diagram shows how the indefinite article, $a(n)$, takes form in different contexts; it becomes "an" before a vowel and "a" before a consonant.

Figure 2

Morphemic rule modeling

$$
\{\text { indefinite article }\} \Rightarrow \text { /an/ / __ vowel }
$$

The gross constituent units, as Lévi-Strauss might call them, of religion are more like morphemes than phonemes. Phonemes have no meaning in and of themselves, whereas morphemes and religious concepts (we resist calling them relemes) have meaning by themselves and can gain more meaning as they are combined.

${ }^{6}$ This diagram only shows a partial rendering of the rules for the expressions of allophones on these phonemes in English. 
Figure 3 shows how contextual expression might be applied analogously to religion.

Figure 3

Contextual expression of religion

$$
\begin{aligned}
\{\mathrm{R}\} \Rightarrow & / \mathrm{r}^{1} / / \ldots \mathrm{X} \\
& / \mathrm{r}^{2} / / \ldots \mathrm{y} \\
& / \mathrm{r}^{3} / / \ldots \mathrm{z}
\end{aligned}
$$

In this analogy, $\{\mathrm{R}\}$ would be any given concept within a religion.

We are using curly brackets because religious concepts are more analogous to morphemes while they exist in the mind as an abstraction, they hold meaning unlike phonemes. The brackets [\#] indicate specific religious behaviors. The contexts $(x, y z)$ can be such conditions like social class, region, or local history. The worldwide community of believers (in our case, the Islamic ummah), as a whole, collectively shares in the transcendent set of religious concepts, even though not all believers draw on every part of the transcendent. Using the above diagram, one can see that by definition $\{R\}$ has no concrete nature until it is put through the gauntlet of rules and restrictions (a grammar), and then further by particular contexts.

Regional variations may show different distributions of specific phonemes or morphemes, but regardless of these variations, they are considered expressions of the same language. For example, figure 4 shows how in northern cities the vowel is pronounced to yield the utterance "pabk the cabr".

Figure 4

Regional variation in vowels

$$
\begin{gathered}
\mid \alpha / \Rightarrow[\mathrm{a}] / \text { northern cities } \\
{[\alpha] / \text { elsewhere }}
\end{gathered}
$$


There is also regional variation in regards to morphemes, the past tense of "to see", or $\{$ saw $\}$ in English can be expressed as saw, seen, and even seed depending on the region or social class of the speaker.

The closest analogy for Islam pertains to the direction of prayers, or qibla, is concerning which Annamarie Schimmel writes

The one direction of prayer around which the people of the world are place, as in were, in concentric circles has been and still is the most visible sign of the unity of the Muslims; it is, so to speak, the specialization [sic] of their belief in one, and only one, God (Schimmel 1991).

While all Muslims pray towards Mecca, there can be variation in how that direction is determined. In the Javanese tradition based on the legends of the Walisongo ${ }^{7}$, Sunan Kalijaga determined the direction of prayer by placing one hand on the center pillar of the mosque he had just built and the other on the kabah in Mecca. The direction determined in that legend is said to be due West. This is the direction traditional Javanese mosques are oriented even when they are built in Suriname, South America (Suparlan 1995, 141). With the rise of modernist movements in the early twentieth century, some Mosques were built with a qibla determined by map and compass. In the diagram, figure 5, slashes /\#/ are used to represent the first level variations because they are still at an intermediate, conceptual level, that is, what the qibla should be. Mosques built in a particular direction or arrows indicated the direction of prayer in a particular building would be concrete expressions.

In Muslim Java, a mosque defines a community because it is the center of prayer, and praying together defines a community, even at significant cost and inconvenience (Lukens-Bull 2003,

${ }^{7}$ Nine saints who brought Islam to Java 
210). According to the Shafi'i madhhab (legal/ritual school) all men in a given geographical community are required to worship in the same Mosque on Fridays except when it is physically impossible for all the inhabitants to meet in one building (Juynboll 1953, 93). This ethic stands even in the face of theological differences. Woodward relates how in one Central Javanese community the mosque is divided in two, so that the Traditionalists may pray due west, as has always been done in Java, and the Reformists may pray facing the direction determined by modern compasses (personal communication, February 1997). This situation can be diagrammed in figure 5 .

Figure 5

Regional variation in direction of prayer

$\{$ Qibla $\} \Rightarrow /$ due West/ /Walisongo tradition $\Rightarrow[$ due West $]$ / community agreement [dual qiblas] / community cohesion /computed compass direction//all others

When the community agrees with the traditional direction, then the qibla is due west. When there is disagreement but the value of community cohesion holds sway, then there will two parts to the mosque. In all other cases, the qibla uses the calculated direction. To illustrate, if there is disagreement about using the traditional qibla and a willingness to deemphasize the importance of community cohesion, then sectarian mosques appear, leading to two mosques in which all congregants accept the consensus qibla (whether it is due West or computed).

We can use diagrams like to this to model the differential expression of Islam in according to the cultural and religious inflections of different groups. Some groups draw on different concepts for the expression and practice of Islam, which produces some of the variation within Islamic societies, but what creates the distinctive variation in these religious practices are 
the cultural inflections places upon concepts, words, and ritual. The chief value of our analogy is the ability to model the relationship between what link differentiates believers in different settings and what ties them together. Such models can point the researcher in new directions for investigation.

\section{Myth, Doctrine, and Grammar}

Prescriptive rule sets, despite being expressions or parole, influence langue, that is they shape how people think about how to speak or to practice religion. Languages have grammar rules and books of grammar usage. Using the idea of generative grammar, we can say the formal grammar found in grammar books and argued over in institutions like the Pusat Bahasa for Indonesian or the Académie Française for French are in fact parole, or expressions, and not langue, which includes the unconscious rules used by native speakers to generate meaningful utterances. To create a set of rules for language or religion, one moves from transcendent understandings that are in and between people's minds and into expressions.

In religion, prescriptions for what followers should do are strongly linked to the mythology ${ }^{8}$. As Malinowski observed:

"Myth fulfills in primitive culture an indispensable function: it expresses, enhances, and codifies belief; it safeguards and enforces morality; it vouches for the efficiency of ritual and contact the practical rules for the guidance of man." (Malinowski 1948, 79).

We concur with Bailey that Malinowski's language is a useful description of myth and morality and that the only thing

${ }^{8}$ The anthropological use of the term "myth" refers to sacred stories which establish a sense of order. The colloquial use of the term meaning a false idea has no place in anthropological discourse. The stories of the Bible, the Quran, and the Bagavad Gita are as much myths as the myths of oral societies. 
wrong with it is its "functionalist aroma of a well-ordered and tranquil world" (Bailey 1977, 16). Whether morals give rise to myths in order to enforce morality, or myths give rise to morality as directives from the divine is a matter we leave to theologians and philosophers because it is completely irrelevant to our argument. Our concern is not about the formation of myths but the use of myths once they have formed.

Without using the whole Lévi-Strauss's approach to myth, we wish to extract his observation that myth is neither langue or parole but has characteristics of both. Langue is the structural dimension of language while parole is the statiscaldimension, that is how language is used. Langue belongs to a reversible time while parole is non-reversible. Myth bridges the past (even the time before time), the present and the future. Using the terms we have chosen in regards to religion, myth stands between the transcendent and the expressed (Lévi-Strauss 1963).

This leads to a difficult question. Are scriptures part of the langue, or transcendent, of religions like Christianity and Islam, or is it an expression? In the great and little tradition approach, scriptures are relegated to the realm of the elite and it has little to do with common practice. Lévi-Strauss argues that langue belongs to reversible time, suggesting that it changes, and $p a-$ role is non-reversible. Myth, Lévi-Strauss argues, combines the properties of langue and parole (or transcendent and expressed to use our terms),

On the one hand, a myth always refers to events alleged to have taken place long ago. But what gives the myth an operational value is that the specific pattern described is timeless; it explains the present and the past as well as the future (LéviStrauss 1963).

Sacred stories like those from the Bible and the Quran are expressions; however they are the purest expressed form of the 
transcendent. In this way, scriptures and other myths are like prescriptive grammars. They are not the core religious concepts that people carry in their head and they use to generate religious behavior, but they do influence them. When people learn the "right way" to speak or to understand religion, they might choose to express what they were taught or they might deliberately violate the rules. Or they might just bend them slightly, or even do their best to have the proscriptive grammar shape their expressions but not fully succeed.

The idea that myths combine attributes of both langue and parole suggest that their structure is langue, subject to evolution, but a particular version of a myth is static. The Quran, the Bible, and other scriptures are textual traditions and, so, unlike the oral traditions examined by Lévi-Strauss ${ }^{9}$ are unchanging in the sense that they have been fixed by convention and are not subject to further revision. So, because scriptures are unchanging they may seem to be parole or expressions, however, if scriptures themselves do not change, the emphasis placed on certain passages certainly does. If we make this accommodation for the difference between textual and oral traditions, then LéviStrauss' observations may still help us explain variation in world religions.

\section{Linguistic Compounds: Syntax, Islam and Ritual}

Syntax, along with morphemes constitutes a grammar, through which meaningful expressions are made. For Islam, these units can be exemplified through ritual and the variations contained within. Ritual practices may vary according to culture, location, and madhhab; they can be said to be inflected

${ }^{9}$ Lévi-Strauss, in looking at Native American mythology, examined myths that changed; his primary interest being their structural transformation (Wiseman and Groves 1997, 140). 
by these contexts. For example, if $\{S\}$ stands for the shared notions of salat then $/ \mathrm{s}^{1} /, / \mathrm{s}^{2} /, / \mathrm{s}^{3} /, / \mathrm{s}^{4} /$, and $/ \mathrm{s}^{5} /$ represents the variations between the five legal-ritual schools (madhhab) ${ }^{10}$. For the most part the variation at this level is about minor matters of practice. For example, prior to the required prayers, there are supererogatory (rawātib) prayers performed. If the prayers are done in a mosque, they are typically done as soon as one enters the mosque and then one waits until the communal prayers begin. How many cycles (rakaah) should be performed differs by madhhab (Bakhtiar 1996:64). As another example, the call to prayers starts by reciting “Allāhu Akbar" four times by all schools except Maliki (Bakhtiar and Reinhart 1996, 64). Further, there can be local differences in meaning, if not form. Figure 5 shows how this two layered variation might take place. An intermediate level, like that shown here, is nearly always present even when not explicit.

Figure 6

Salat filtered by madhhab and local debates

$$
\begin{aligned}
& \{\mathrm{S}\} \Rightarrow / \mathrm{s}^{1} / / \text { Jafariy } \\
& / \mathrm{s}^{2} / / \text { Hanbaliy } \\
& / \mathrm{s}^{3} / / \text { Hanafiy } \\
& / \mathrm{s}^{4} / / \text { Malikiy } \\
& / s^{5} / / \text { Shaficiy } \\
& / \mathrm{s}^{1} / / \text { Jafariy } \Rightarrow\left[\mathrm{s}^{5_{a}}\right] / \text { colonialism } \\
& {\left[\mathrm{s}^{5 \mathrm{~b}}\right] \text { / Gayo worldview }} \\
& {\left[\mathrm{s}^{\mathrm{sc}}\right] / \text { Indonesian sociability }}
\end{aligned}
$$

Bowen (1989) explores three cases in Indonesia where debate over proper performance of salat ( 5 daily prayers) highlights different socio-political meanings of this ritual. In one case, the emphasis on congregational salat as a way to realize the egalitarian and universal character of the congregation granted

${ }^{10}$ There are four Sunni maddhab: Maliki, Hanbali, Hanafi, and Shafi and one Shia maddhab, Jafari. 
a degree of political unity in colonial Aceh (Bowen 1989, 602). In another case, the debate centered on whether to recite the prayers audibly among the Gayo in highland Aceh. Traditional Gayo believed salat to be a communication act and therefore had to be performed out loud so that God could hear them. This practice brought the Gayo into conflict with reformist Muslims (Bowen 1989). In the final case, the concern was who should pray with whom. The idea that people might violate Indonesian notions of sociability and not conduct salat with whoever is present wherever they might be was anathema. About these three cases, Bowen states,

In each of the three Indonesian cases a social group has emphasized certain features of the salat in its efforts to define or maintain a particular social form. The disputes that ensued have implicated wider social, political and religious values, but they have been argued explicitly as competing interpretations of the role and form of the salat itself (Bowen 1989, 609).

Small distinctions such as these are the basis for much debate among the Muslims. But in the long run, inflections such as these are an anthropologist's window into understanding the cultural inflections on Islam as well as the portion of the transcendent that are being expressed within that given Muslim community.

The exact nature of Muslim rituals in Java, Indonesia, the Middle East, and Africa all vary and much of that variation reflects the manner in which their religious practices have been culturally inflected. The festivals using trances states in Java would scarcely understood by Muslims in Iraq or Morocco, for their expression of Islamic religiosity do not include this type of ritual or concept. Geertz (1968) attempted to tackle a comparative project by examining two different culture linked by the same religion, Islam. Although they share religious concepts, the way the concepts are expressed differently. For example, saints 
(wali, marabout) exist in both Java and Morocco. However the quietist Sunan Kalijaga would hardly be seen are worthy of the title in Morocco. Likewise, the Berber Zealot Lyusi is far too course and unrefined to be considered a saint by the Javanese. ${ }^{11}$ As Geertz says,

On the Indonesian side, inwardness, imperturbability, patience, poise, sensibility, aestheticism, elitism, and an almost obsessive self-effacement, the radical dissolution of individuality; on the Moroccan side, activism, fervor, impetuosity, nerve, toughness, moralism, populism, and an almost obsessive self-assertion, the radical intensification of the individuality (Geertz 1968, 54).

The author will use the term "quietist" as a gloss for the constellation of traits that Geertz attributes to Indonesia (properly Java) and "activist" as the umbrella term for the traits Geertz attributes to Morocco. We can then model the differences and similarities in Javanese and Moroccan sufi saints, figure 7.

Figure 7

Saints in different muslim societies

$\{$ Wali $\} \Rightarrow$ /quietest// Java $\Rightarrow$ /activist/ / Morocco

Here we can see the utility of our modeling technique. To stop here and declare that the difference is due to culture is unsatisfactory. Geography is not destiny; mere location did not make for the differences.

We need to examine the various ways in which Java and Morocco differ. There are four things we can examine: differences in madhhab, difference in Sufi practices and brotherhoods, the pre-Islamic context, and modal personalities. As for madhhab,

${ }^{11}$ In Islam Observed (1968) conflates Indonesia with Java. In comparing Indonesian with Morocco, he was really comparing a Javanese saint with a Moroccan one. Here we correct Geertz' mistake and clearly identify Kalijaga as Javanese. 
Java is predominately Shafi' $\mathrm{i}$, whereas Morocco is predominately Maliki. In this particular case, there is little to be found that can be traced to madhhab, but certainly in other areas of Muslim life, part or even most of the difference might be explained by which madhhab is followed in a particular region. There are some sufi brotherhoods that are found in both Java and Morocco. Specifically, in Java there is a branch of the Shadhiliyah order (Dhofier 1994, 142), which also had branches in West Africa (Johns 1987, 348; Massignon 1953, 577; Eickleman 1976).

Geertz explains attributes the forms of Islamic spirituality take in Java as the result of syncretism with animist and Hindu pre-Islamic Javanese beliefs. Judith Becker argues that once Indian tantric mystical forms were firmly entrenched in the culture they continued to shape later religious expression (Becker 1993). Islam was brought to the region by merchants who were also Sufi mystics. They picked up on the strong interest in mysticism and emphasized that dimension of their faith. So successfully did they contextualize Islam with the existing tantric forms that Indonesians who still practice the Hindu-Buddhist forms use Arabic terms, lahir (external) and batin (internal) to describe them (Geertz 1960, 232). This is at best a partial explanation. If a Hindu heritage was sufficient explanation for the difference between Java and Morocco then we would expect Indian Muslims to value the same traits in a saint Modal personalities might need to included to round out an explanation. Culturally, the Javanese value the traits attributed to Kalijaga and attempt to cultivate them in themselves.

In much the same light, circumcision can differ between cultures. In Java, male circumcision occurs at the onset of puberty. A Pakistani Imam told that it is more normal to circumcise males when they are babies, following certain Hadith traditions. Female circumcision is even more varied from the merely sym- 
bolic in Indonesia, which can either prick the clitoris or cut a plant (turmeric or ginger) placed over the genitals to more extreme forms (Feillard and Marcoes 1998; United States Department of State 2001). There are even some Muslim websites that argue against any form of circumcision (male or female) based on Quranic passages (Quranic Path 2018).

Not all the differences between practices in different populations is due to cultural inflections. As indicated above in figure 5 , madhhab influences ritual. We might expect to find greater similarities in ritual practice between Java and Somalia, both of which were historically Shafi'i in orientation, than say Java and Morocco, which historically was Maliki. Differences between Java and Somalia will need to be explained primarily in terms of cultural inflection, however to do so for Java and Morocco, as Geertz (1968) did may be skipping the important step of understanding some of the conceptual differences between the Shafi'i and Maliki madhhabs. The kind of modeling we advocate would allow an ethnographer to identify areas for further investigation. For example, in the case of the symbolic circumcision of Javanese girls, it would help us identify areas to explore in trying to puzzle out why the Javanese bother with female circumcision at all. In this case, it may require looking at the way different concepts combine.

Different combinations of concepts can result in various inflected meanings, and meanings carry vary depending upon a number of external factors. Religious concepts combine so that in regards to the Javanese slametan Woodward finds congruency with hadith about the Prophet sharing meals with followers, and is a prime example of local Islam (Woodward 1988, 62-63). Another Islamic aspect of the slametan is the fact that the invited guests include the host's neighbors (Woodward 1988, 81-82). The Early Code of Javanese Muslim Ethics (Drewes 1978) stress- 
es the importance of kindness to Muslim neighbors. The invitation of neighbors to slametan fulfill an important Islamic social obligation. Clifford Geertz (1960) argues that the the slametan is a pre-Islamic Javanese ritual whereas Woodward argues that it is Islamic. These are not mutually exclusive points.

Figure 8

Modeling the slametan

$$
\begin{aligned}
\{\text { blessing }\}+\{\text { communal meal }\}+\{\text { neighborliness }\} \\
\Rightarrow / \text { kenduren-slametan//Islamized concepts } \\
\text { / "Hindu" slametan//non-Islamized concepts }
\end{aligned}
$$

These different expressions of the same concepts or the addition or omission of concepts from the religious practices are all a result of the relationship between the transcendent and the expressed. You will not find the practice of the transcendent in any one given group. The transcendent is entirely too immense to be held by any one group or person, but by definition, is something that is held by a collective (Saussure 1972). Thus, the combinations of different concepts held within the body of the transcendent results in different forms of expression of Islam throughout the world.

\section{Creoles and Pidgins}

There are "islams" that call themselves Islam, for example the Nation of Islam, that really do not have great deal of Islamic content. The Nation of Islam had a number of unique doctrines including the divinity of WD Fard, the prophet hood of Elijah Muhammad, and the separation of blacks from whites, who were seen as depraved and as "devils" (Berg 1999). In regards to the divinity of WD Fard, this is not a case of cultural inflection, but a different constituent belief. While there is some variation 
in how Muslim understand the nature of God, attributing divinity to an identifiable man is beyond the pale. Within our linguistic analogy, the best way to deal with these movements is to consider them pidgins and creoles. Creole speakers might even insist that they are speaking the standard dialect. Ronald Kephart reports that in 1979, a French Creole speaker in Carricou greeted him in Creole by asking, "Do you speak French?” He did not ask if Kephart spoke Creole because he did not think of himself as speaking anything other than French (Personal Communication, September 2010). Likewise, Elijah Muhammad taught that his movement was Islam and introduced the Quran to the movement (Berg 1999).

\section{Conclusion and Future Directions}

The goal of this paper was to begin a new discussion of Islam as a language with a symbol set, lexicon, syntax, grammar, and different forms that are all interrelated and are analogous to a human language.

Our model is by no means complete, but rather poses new questions to be explored, namely how anthropologists find themselves observing very different forms of Islam across cultures and how best to understand how these different expressions of the same religion may be related. Some of the dynamics in our model are well known in humanities approaches to religion; our contribution is to set some scientific rigor to the understanding of these processes. This rigor can help identify where the research may need to dig deeper to explain observed variation; if when drawing a model there is a missing step, then that is an area for research.

Our model about the relationship between the transcendent and the expressed in Islam is not wholly new, but rather builds upon the work of other anthropologists and seek to refine the definitions of these two concepts within the mechanism through 
which they interact. From this point, we can see that anthropologists studying Islam must shift or refocus their research questions to take into account the nature of what they are studying. In one sense, Islam cannot be found in the texts. In another sense, what makes Islam a world religion and not just a collection of local practices is found primarily in the texts. In the past, anthropologists have sought to understand the diversity in Islam and other world religions. Some approaches have been linguistic and focus on our attention on symbol sets and discourse. Others have been non-linguistic in nature and focus our attention on large trends like "great" and "little" traditions, or universal, received, and local forms of Islam. We have argued that a fuller linguistic analogy allows the dynamic nature of Islam as illustrated in linguistic models to be linked to the structural dimensions found in the approach taken by Redfield and others. Adding to the linguistic analogy, the analogues of both morphemes and dialects yields a richer understanding of what links divergent practices. We have not explored here all the possible linguistic analogies that could yield fruitful research. Nor have we fully demonstrated the research and analytical implications. That work will have to be done in more ethnographically focused efforts.

\section{Bibliography}

Antoun, Richard T. 1989. Muslim Preacher in the Modern World. Princeton, NJ: Princeton University Press.

Asad, Talal. 1986. "The Idea of an Anthropology of Islam.” In Occasional Papers Series. Washington, D.C.: Center for Contemporary Arab Studies, Georgetown University.

Bailey, F.G. 1977. Morality and Expediency: The Folklore of Academic Politics. Chicago: Aldine Pub. Co.

Bakhtiar, Laleh, and Kevin A. Reinhart. 1996. Encyclopedia of Islamic Law : A Compendium of the Views of the Major 
Schools. ABC International Group.

Becker, Judith. 1993. Gamelan Stories: Tantrism, Islam, and Aesthetics in Central Java. Tempe, AZ: Program for Southeast Asian Studies, Arizona State University.

Berg, Herbert. 1999. "Elijah Muhammad and the Qur'an: The Evolution of His Tafsir." Muslim World 89 (1): 42-55.

Bhardwaj, Surinder M. 1998. "Non-Hajj Pilgrimage: A Neglected Dimension of Religious Circulation." Journal of Cultural Geography 17 (2): 69-87.

Bowen, John R. 1989. "Salāt in Indonesia: The Social Meanings of an Islamic Ritual." Man (N.S) 24: 600-619.

_. 1993a. "Discursive Monotheisms." American Ethnologist 20 (1): 185-90.

-1993b. Muslims through Discourse: Religion and Ritual in Gayo Society. Princeton, NJ: Princeton University Press.

- 2012. A New Anthropology of Islam. Cambridge: Cambridge University Press.doi:10.1017/CBO9781139045988.

Chambert-Loir, Henri, and Anthony Reid. 2002. The Potent Dead. Ancestors, Saints and Heroes in Contemporary Indonesia. Honolulu: University of Hawai'i Press.

Chandler, Daniel. 2006. Semiotics for Beginners. Cardiff, Wales: University of Wales.

Chomsky, Noam. 2002. Language and the Brain. Cambrdige: Cambridge University Press.

Davies, Merryl Wyn. 1988. Knowing One Another: Shaping an Islamic Anthropology. New York: Mansell Pub.

Dawkins, Richard. 1976. The Selfish Gene. Oxford: Oxford University Press.

Dhofier, Zamakhsyari. 1994. Tradisi Pesantren: Studi Tentang Pandangan Hidup Kiai. Jakarta: LP3ES. 
Drewes, Gerardus. 1978. Early Code of Javanese Muslim Ethics. The Hague: Martinus Nijhoff.

Eickleman, Dale F. 1976. Moroccan Islam: Tradition and Society in a Pilgrimage Center. Austin: University of Texas Press.

— 1982. "The Study of Islam in Local Contexts." Contributions to Asian Studies 17: 1-18.

El-Zein, Abdul Hamid M. 1977. "Beyond Ideology and Theology: The Search for the Anthropology of Islam." Annual Review of Anthropology 6: 227-54.

Fairclough, Norman. 1989. Language and Power. London: Longman.

Feillard, Andree, and Lies Marcoes. 1998. "Female Circumcision in Indonesia: To 'Islamize' in Celebration or Secret." Archipel 56: 337-67.

Friedlander, Shems. 1992. The Whirling Dervishes: Being an Account of the Sufi Order Known as the Mevlevis and Its Founder the Poet and Mystic Mevlana Jalalu'ddin Rumi. New York: State University of New York Press.

Geertz, Clifford. 1960. The Religion of Java. New York: The Free Press.

- 1968. Islam Observed: Religious Development in Morocco and Indonesia. New Haven, CT: Yale University Press. doi:http://arxiv.org/abs/1602.07274.

. 1973. Interpretation of Cultures. New York: Basic Books. doi:10.1016/0039-9140(73)80012-8.

Goldziher, Ignaz. 1910. Introduction of Islamic Theology and Law. Princeton, NJ: Princeton University Press.

Gunaratna, Rohan. 2002. Inside Al-Qaeda. New York: Columbia University Press.

Hartley, Elda. 1974. "Sacred Trances in Java and Bali." West- 

port: Hartley Film Foundation.

Johns, A.H. 1987. “Tariqah.” In The Encyclopaedia of Religion, edited by Mircea Eliade, 342-252. New York: Macmillan Publishing Company.

Juynboll, Th. W. 1953. "Djum'a.” Shorter Encyclopedia of Islam. E.J. Brill; Luzac \& Co.

Khanna, Parag. 2009. "Why We Should Get Rid of the Term Muslim World." The Washington Post, April 19.

Lee, Martha. 1996. The Nation of Islam: An American Millenarian Movement. New York: Syracuse University Press.

Lévi-Strauss, Claude. 1963. Structural Anthropology. New York: Basic Books.

- 1998. "The Meaning and Use of the Notion of Model." In Teaching Lévi-Strauss. Atlanta: Scholars Press.

Loeffler, Reinhold. 1988. Islam in Practice: Religious Beliefs in a Persian Village. New York: State University of New York Press.

Lukens-Bull, Ronald. 1999. "Between Text and Practice: Considerations in the Anthropological Study of Islam." Marburg Journal of Religion 4 (2): 10-20.

—. 2003. "An Accidental Imago Mundi: Spatializing Religious and Social Change in Islamic Java." In Sacred Places and Modern Landscapes: Sacred Geography and Social-Religious Transformations in Asia, 203-26. Tempe, AZ: Arizona State University Program for Southeast Asian Studies.

Malinowski, Bronislaw. 1948. Magic, Science and Religion and Other Essays. Glencoe: The Free Press.

Marranci, Gabrielle. 2008. The Anthropology of Islam. Oxford: Berg Publishers Bloomsbury Academic. doi:10.5040/9781474215626. 
Massignon, L. 1953. "Tarika.” In Shorter Encyclopaedia of Islam, edited by H.A.R.Gibb and J.H. Kramers, 573-78. Leiden: E.J. Brill.

Quranic Path. 2018. "Circumcision - Does the Quran Approve It?" QuranicPath.Com. Accessed December 24. http:// www.quranicpath.com/misconceptions/circumcision.html.

Redfield, Robert. 1956. Peasant Society and Culture. Chicago: Unversity of Chicago Press.

Roy, Oliver. 2004. Globalized Islam: The Search for a New Ummah. New York: Columbia University Press.

Saniotis, Arthur. 2004. "Tales of Mastery: Spirit Familiar in Sufis' Religious Imagination.” Ethos 32 (3): 397-411.

Saussure, Ferdinand. 1972. Course in General Linguistics. Edited by Roy Harris. Chicago: Open Court.

Schimmel, Annemarie. 1991. "Sacred Geography in Islam.” In Sacred Places and Profane Spaces: Essays in the Geographics of Judaism, Christianity, and Islam, edited by Jamie Scott and Paul Simpson-Housely. New York.

Subtelny, M.E. 1989. "The Cult of Holy Places: Religious Practices among Soviet Muslims." Middle East Journal 43 (4): 593-604.

Suparlan, Parsudi. 1995. "The Javanese in Suriname: Ethnicity in an Ethnically Plural Society.” Tempe, AZ: Arizona State University, Program for Southeast Asian Studies.

United States Department of State. 2001. "Indonesia: Report on Female Genital Mutilation (FGM) or Female Genital Cutting (FGC)." Refworld.Org. https://www.refworld.org/ docid/46d57879c.html.

Varisco, Daniel Martin. 2005. Islam Obscured: The Rhetoric of Anthropological Representation. New York: Palgrave Macmillan. 